\title{
Role of genetic markers in the prediction of classification of Czech Large White gilts to a hyperprolific line
}

\author{
NADĚŽDA KERNEROVÁ ${ }^{1}$, VÁCLAV MATOUŠEK', ANNA ČERMÁKOVÁ ${ }^{2}$ and MARIE \\ FORBELSKÁ ${ }^{3}$
}

'Department of Special Animal Husbandry, Faculty of Agriculture, University of South Bohemia in České Budějovice, Czech Republic, ${ }^{2}$ Department of Applied Mathematics and Informatics, Faculty of Economics, University of South Bohemia in České Budějovice, Czech Republic, ${ }^{3}$ Department of Mathematics and Statistics, Faculty of Science, Masaryk University in Brno, Czech Republic

\begin{abstract}
The objective of statistical evaluation (discriminant analysis) was to find out whether the genetic endowment the gilt was born with is a high-quality discriminator for prediction of its future classification to a hyperprolific line (HPL). Based on the results a conclusion is drawn that the gilt with genotype CC of ESR gene will be classified to HPL in high probability - if the effect of this gene is not reduced by an interaction with other genes. The statistical analysis did not reveal a significant effect of $F S H B$ gene in Czech Large White sows on their future classification to HPL. On the contrary, PRLR gene is a highquality discriminator. Obviously, it is highly probable that the gilt with genotype $B B$ will be classified to HPL. It is to state from the analysis of pairs of the studied genes that the adult gilt with genotype $C C$ of $E S R$ gene and genotype $B B$ of $F S H B$ gene and/or PRLR gene will be classified to HPL in all probability. $P R L R$ gene has a dominant effect in the pair ESR and PRLR. Genotype BB of PRLR gene (the most beneficial of the genotypes from the aspect of future classification of gilts to HPL) markedly increases posterior probability of alleles of ESR gene. If the classification of a gilt to HPL is predicted from the analysis of all three genes, the results of partial analyses are confirmed in most cases. The results of the experiment indicate a possible prediction of gilts on the basis of their genotype for classification to HPL but it cannot be confirmed that the identified »beneficial " genotype will always be expressed in different populations by an increase in reproductive traits.
\end{abstract}

Keywords: pig, Czech Large White, litter size, candidate genes, ESR, FSHB, PRLR

\section{Zusammenfassung}

\section{Eignung genetischer Marker für eine Voraussage von Sauen des} Tschechischen Weißen Edelschweins für eine superfruchtbare Linie

Das Ziel der Arbeit bestand in der mittels Diskriminanzanalyse vorgenommenen Prüfung ob die angeborene genetische Ausstattung als hochwertiger Marker für eine Voraussage einer Einordnung in eine superfruchtbare Sauenlinie (HPL) genutzt werden kann. Es wurde festgestellt, dass Sauen mit dem Genotyp CC des ESR Gens dieser Linie zugeordnet werden können wenn dieser Effekt nicht durch Interaktionen mit anderen Genen verringert wird. 
Kein signifikanter Effekt ergab sich diesbezüglich bei dem $F S H B$ Gen in der untersuchten Population. Das galt das nicht für das PRLR Gen bei dem die BB Genotypen für diese Linie prädestiniert waren. Die größte Wahrscheinlichkeit, dass Sauen in die HPL Linie eingeordnet werden bestand in der Kombination CC Genotyp des ESR Gens und BB Genotyp des FSHB und/oder des PRLR Gens. Der BB Genotyp des PRLR Gens, welches aus der Sicht einer Einordnung der Sauen in die HPL als der günstigste Genotyp angesehen wird, erhöht wahrscheinlich merklich den Anstieg der ESR Gen Allele. Erfolgt mit Hilfe der Analyse aller drei Gene eine Einordnung der Sauen in die HPL Linie so bestätigten sich in den meisten Fällen die Ergebnisse der Teilanalysen. Die Ergebnisse der Untersuchungen lassen eine mögliche Voraussage der Einordnung von Sauen in die HPL auf Grund ihres Genotyps erwarten. Es konnte nicht bestätigt werden, dass die hier als günstige Genotypen ermittelten auch in anderen Populationen eine Verbesserung der Fruchtbarkeitsleistungen erwarten lassen.

Schlüsselwörter: Schwein, Tschechisches Weißes Edelschwein, Wurfgröße, Kandidatengen, ESR, FSHB, PRLR

\section{Introduction}

In France the method of hyperprolific lines (HPL) contributed to an increase in the genetic potential of pigs to a high level. BIDANEL and DUCOS (1994) reported that HPL of daughters of HPL boars of Large White breed exhibited a genetic improvement of the litter size by 0.9 piglet per litter. A need to increase the level of prolificacy in dam breeds resulted in development of methodology for the production of HPL also in the Czech Republic.

Oestrogen receptor gene is one of the best-known genes studied in relation with sow prolificacy. According to ROTHSCHILD (1996) the preferred allele D of ESR gene was associated with an increase in the number of piglets in the Large White breed by $0.4-0.5$ piglet per litter. A significant effect of ESR locus on the number of weaned piglets $(P \leq 0.01)$ in Large White breed was reported by OMELKA et al. (2006). However, they observed a negative effect of $D D$ genotype on this trait. The influence of the ESR gene as a quantitative trait locus (QTL) for litter size in a German Landrace population was analysed by DRÖGEMÜLLER et al. (1999). They did not find any Pvu II polymorphism. The associations of ESR genotypes with reproduction traits of hybrid sows were studied by DEPUYDT et al. (1999). The assumed effect of ESR genotypes on fertility was not confirmed. BUSKE et al. (2006) investigated if the genotype of the gene ESR2 was associated with litter size in a commercial pig cross population. Sows were divided into two extreme performance groups, with large $(\geq 14.3)$ and with small litter size $(\leq 11.3)$. No association was found between different ESR2.

The results of ZHANG et al. (2004) showed that the polymorphism of FSHB locus was significantly associated with litter size. Total number born and number born alive of sows with genotype $B B$ were higher, with the additive effect 1.02-1.42 and 1.04-1.27 piglets per litter, respectively. LINVILLE et al. (2001) did not prove any significant associations between polymorphic markers and studied genotypes of FSHB gene. Nevertheless, they admitted that other genetic changes within candidate genes influenced the studied traits (linear model). HUMPOLICEK et al. (2006) examined the effects of FSHB on the performance 
of Large White sows in three different herds. The influence of FSHB was not very conclusive in the studied populations; it was different depending on the herd in which the sows were kept or on the set of analyzed litters. The polymorphisms of ESR1, FSHB and RBP4 genes (PCR-SSCP, PCR and PCR-RFLP) in a Large White herd and in a Landrace herd were detected by WANG et al. (2006). They found polymorphisms for the three genes in Large White besides the ESR1 and RBP4 genes in Landrace. The results showed that the highest genotype effects were exerted by ESR1 among these three genes.

According to VINCENT et al. (1998) PRLR gene seems to have a similar effect like ESR gene, but rather in the lines of Landrace origin, while the effect of ESR receptor is expressed mainly in Large White and Meishan breeds. DRÖGEMÜLLER et al. (2000) reported that in the Duroc breed a difference between genotypes $A A$ and $B B$ was 1 piglet born alive per litter; VAN RENS and VAN DER LENDE (2002) stated that (Large White $\times$ Meishan) gilts of genotype $A A$ of $P R L R$ genotype delivered more piglets born and born alive that gilts of genotype $B B$.

The objective of statistical evaluation was to find out whether the genetic endowment of the gilt was born with is a high-quality discriminator for prediction of its future classification to the HPL.

\section{Material and methods}

Data from performance testing of reproductive traits of Czech Large White sows coming from three elite breeding herds were used in this study. We evaluated 98 sows with known genotypes of three candidate genes for reproduction:

- oestrogen receptor (ESR) with alleles $C(120 \mathrm{bp})$ and $D(65,55 \mathrm{bp})$

- follicle-stimulating hormone (FSHB) with alleles $A(208,173,159,84 \mathrm{bp})$ and $B(332$, 208,84 bp)

- prolactin receptor $(P R L R)$ with alleles $A(85,59,19 \mathrm{bp})$ and $B(104,59 \mathrm{bp})$.

It is so called "training set" (in accordance with statistical terminology). Out of the studied sows, 51 sows were classified to the HPL while 47 sows were classified to the basic herd $(x)$. Genotypes were determined by molecular genetics methods PCR-RFLP in Laboratory of Applied Genetics of Mendel University of Agriculture and Forestry in Brno (LamGen). DNA was isolated from blood samples with the addition of anticoagulant EDTA.

The statistical analysis of data was based on methods of discriminant analysis when we used the discriminant analysis for two groups (HPL, basic herd). The genotypes (ESR, $F S H B$ and $P R L R$ ) are specific because they are discrete random variables. Therefore the methods of discrimination for categorical data were used (AITCHISON \& AITKEN 1976, HALL 1981, ČERMÁKOVÁ \& FORBELSKÁ 2004). The personal study was employed for these purposes because commercial statistical software packages do not comprise any discrete models.

For discrimination were applied both parametric discrimination (see models with the multinomial estimator) and nonparametric discrimination based on kernel estimators of probability functions figuring in decision rules (see models with binary or nominal kernel estimator). The quality of discrimination was evaluated by estimations of probabilities of misclassification, applying two methods: plug-in method and resubstitution method (ČERMÁKOVÁ \& FORBELSKÁ 2004). These methods of statistical analyses were used 
because of the relatively small size of the training set. If we obtained significantly different results by different methods, generalisation for the population would not be correct. It is to note that we took advantage of nonparametric methods enabling to estimate posterior probability even when the particular combinations of alleles (e.g. $D D$, $A B, B B)$ did not occur in the training set. Parametric methods do not provide such a possibility. The statistical analysis considered all theoretical variants, i.e. it was carried out for each separate gene, for combinations of two genes and for the vector of three genes. Taking into account the small size of the training set it can considerately be deduced from the results whether in relation to prolificacy the genes act either autonomously or it is possible to expect their interaction.

\section{Results and discussion}

The summary of classification results of parametric (multinomial) model and two nonparametric (binary and nominal kernel) models and error rates are presented in Figures 1 through 7. The left horizontal stacked bar graph shows estimated posterior probabilities of individual genotypes. The right horizontal bar graph shows the achieved contribution of individual genotypes (scores $q_{i}$ ) to the total error rate (ER) based on posterior probabilities (plug-in estimates). For estimating error rates, the resubstitution method (apparent error rate APER) is also available.

Figures 1-7 show that the results obtained by parametric and nonparametric methods do not differ significantly from each other.

Therefore we can draw a conclusion that gene ESR (Figure 1) if its effect is not decreased through interaction with other genes influences reproductive traits in this sense: the gilt that will be born with genotype CC of ESR gene will be classified in high probability to HPL $\left(p_{H P L, C C}=0.75\right)$. The probability of misclassification of $C C$ genotype to $\mathrm{HPL}$ is not very high. The two remaining genotypes are indifferent for the prediction of future classification of gilts to HPL (posterior probability is slightly below the level 0.5 , so it is not possible to draw a conclusion concerning the future with sufficient reliability). LEGAULT et al. (1996) did not report any significant differences in the genotype frequency of ESR gene between HPL and control group of Large White breed, the genotypes did not show a significant effect on litter size in any line. MATOUŠEK et al. (2003) analysed the relationship of ESR genotypes with the traits of litter size in sows in two elite breeding herds. In one herd, sows of genotype $D D$ had a significantly higher number of piglets while in the other herd the examined reproductive traits were higher in sows of genotype CC.

The statistical analysis did not indicate a significant effect of $F S H B$ gene on their future classification to HPL (Figure 2). The value of posterior probabilities is about 0.5 ; so FSHB gene does not appear to be a high-quality discriminator between the two classes in the Czech Large White breed. But it does not imply that it does not contribute to discrimination in interaction with other genes. HUANG et al. (2000) found out by $0.55-2.21$ piglets born alive more per litter in gilts of genotype $B B$ compared to gilts of genotype $A A$.

$P R L R$ gene belongs to high-quality discriminators. Figure 3 illustrates that the gilt with genotype $B B$ will be classified in high probability to HPL $\left(p_{H P L, B B}=0.8\right)$. This conclusion is supported by the fact that the probability of misclassification of the gilt with genotype 
$B B$ of $P R L R$ gene is low (it lies deep below the mean value of scores). The gilt with genotype $A A$ would seem not to have a very high chance to be classified to HPL. But we cannot draw such a conclusion due to high probability of misclassification. According to DVOŘÁK (1999) the average effect of allele $B$ of $P R L R$ gene in parity 1 is 0.25 piglet more. DRÖGEMÜLLER et al. (2001) observed a small additive effect of allele $B$ of $P R L R$ gene on litter size in the Duroc line (linear model). VAN RENS et al. (2003) believed that $P R L R$ gene was a candidate gene for ovulation rate rather than for litter size (linear model).

If we predict future classification of sows from the aspect of genetic endowment on the basis of parallel analysis of two or even three genes (Figures 4-7), we have to be considerate because only very few animals can have the particular genotype combination.

It seems that $F S H B$ gene that was not a good discriminator (Figure 2) will express itself in combination with ESR (Figure 4) or PRLR (Figure 6) gene. Genotype BB of FSHB gene in synergy with the genotype of $E S R$ gene or $P R L R$ gene increases more or less the probability that the adult gilt will be classified to HPL. E.g. in the combination of genotype $B B$ of FSHB gene and genotype $C C$ of ESR gene posterior probability will increase from the value $p_{H P L, C C}=0.75$ (Figure 1) to the value $p_{H P L, C C E B B}=0.85$ (Figure 4). In the combination of genotype $B B$ of $F S H B$ gene and genotype $B B$ of $P R L R$ gene (Figure 6) posterior probability increased from $p_{H P L, B B}=0.8$ (Figure 3) to $p_{H P L, B B \& B B}=0.9$ (Figure 6). Genotype $A B$ of $F S H B$ gene and genotype $D D$ of $E S R$ gene significantly increase the probability of classification to HPL from $p_{H P L, D D}<0.5$ (Figure 1) to $p_{H P L, D D \& A B}>0.5$ (Figure 4) while genotype $A B$ of FSHB gene and genotype $B B$ of $P R L R$ gene decrease such probability (Figure 6). It is possible to conclude from the analysis of pairs of these genes that the adult gilt born with genotype $C C$ of $E S R$ gene and genotype $B B$ of $F S H B$ gene will have the highest probability of being classified to HPL whereas the prediction score is low (Figure 4); the same will apply to genotype $B B$ of $P R L R$ gene and FSHB gene, also with the low score of prediction error (Figure 6). On the contrary, very low probability of classification to HPL was determined in gilts with scarce combinations of genotypes, i.e. genotype $C D$ (and/or $C C$ ) of $E S R$ gene and genotype $A A$ (and/or $A B$ ) of $F S H B$ gene (Figure 4) and genotype $A A$ of $P R L R$ gene and FSHB gene (Figure 6). CHEN et al. (2001) drew a conclusion that the effect of ESR and FSHB genes on litter size made it possible to improve reproductive traits through markerassisted selection.

The analysis of the pair of ESR and PRLR genes provided interesting results (Figure 5). The effect of $P R L R$ gene was dominant in this pair. Genotype $B B$ of $P R L R$ gene (it is the most beneficial of all genotypes from the aspect of future classification of a gilt to HPL) markedly enhances posterior probability of ESR gene alleles. E.g. in genotype CD of ESR gene $(p=0.4)$, i.e. on the basis of the analysis through ESR gene only, it is not possible to predict the classification of a gilt to HPL, but in the combination of genotype $C D$ of $E S R$ gene and genotype $B B$ of $P R L R$ gene it can be stated in high probability that this gilt will be classified to HPL. Genotype $A B$ of $P R L R$ gene behaves indifferently in relation to ESR gene while genotype $A A$ of $P R L R$ gene decreases the effect of $E S R$ gene with respect to the future classification of gilts to HPL. E.g. if we analysed ESR gene only, the probability of the gilt with genotype $C C$ to be classified to HPL would be high. However, if we also consider $P R L R$ gene and if the gilt is of genotype $A A$, its probability of being classified reliably to HPL at an adult age will decrease to $p=0.5$. VAN RENS (2001) analysed the 
combinations of ESR and PRLR genotypes. She reported that each gene influenced different components of litter size. SOUTHWOOD et al. (1999) did not detect any interactions between genes for prolactin and oestrogen receptor.

If the gilt classification to HPL is predicted by the analysis of all three genes, the results of partial analyses are mostly confirmed: e.g. a marked contribution of genotype $C C$ of ESR gene with the positive association of genotype $B B$ of $F S H B$ gene and augmentation effect of genotype $B B$ of gene $P R L R$.
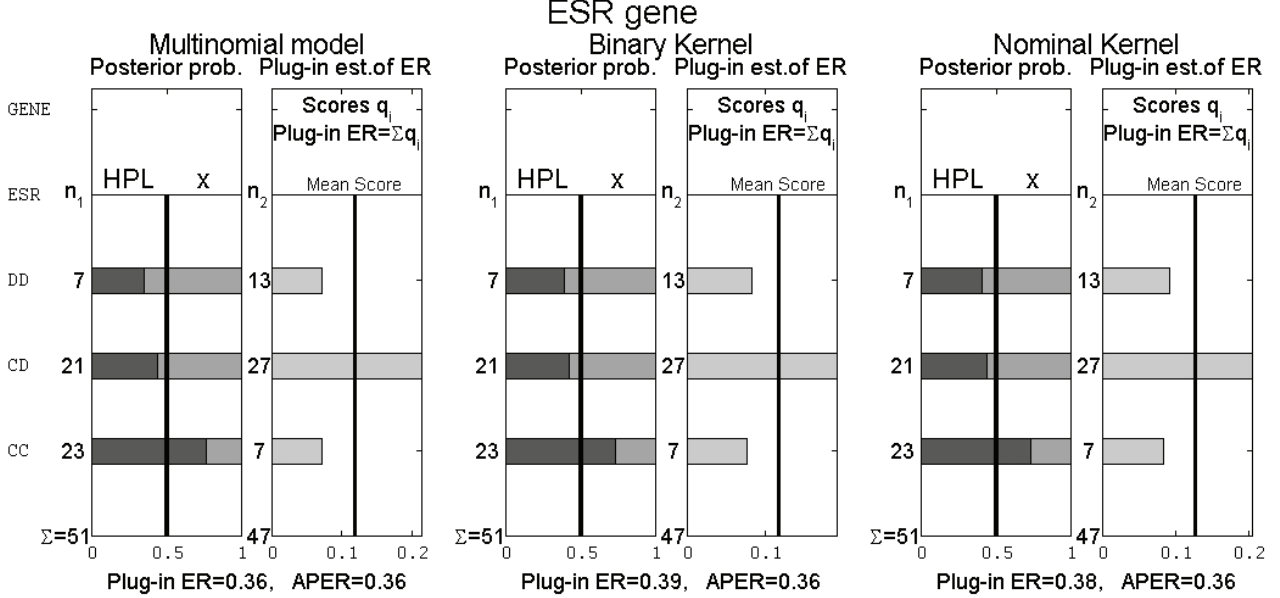

All estimated values of the total error rate are in the range: $0.36-0.39$. Each of the methods classifies sow with genotype $D D$ of ESR gene into not HPL (posterior probabilities $p_{H P L, D D}<p_{X, D D}$ ) and sow with genotype $C C$ into HPL $\left(p_{H P L, C C}>p_{X, C C}\right)$.

Figure 1

Probability of the future classification of sows to HPL determined by the analysis of genotypes of ESR gene Wahrscheinlichkeit künftiger Sauenzuordnung in die superfruchtbare Linie (HPL) auf Grund der Genotypenanalyse des ESR Gens
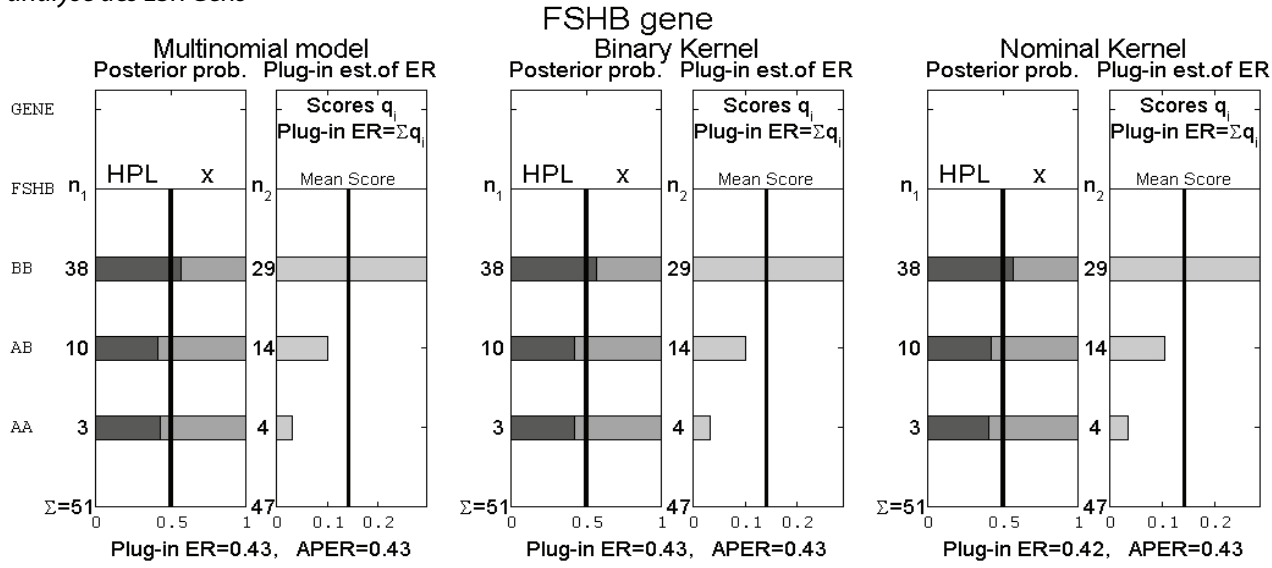

All estimated values of the total error rate are about 0.43 . Parametric and nonparametric methods classify sow with genotype BB of FSHB gene into HPL (posterior probabilities $p_{H P L, B B}>p_{X, B B}$ ) and sow with genotype AA into not HPL $\left(p_{H P L, A A}<p_{X, A A}\right)$.

Figure 2

Probability of the future classification of sows to HPL determined by the analysis of genotypes of FSHB gene Wahrscheinlichkeit künftiger Sauenzuordnung in die HPL auf Grund der Genotypenanalyse des FSHB Gens 

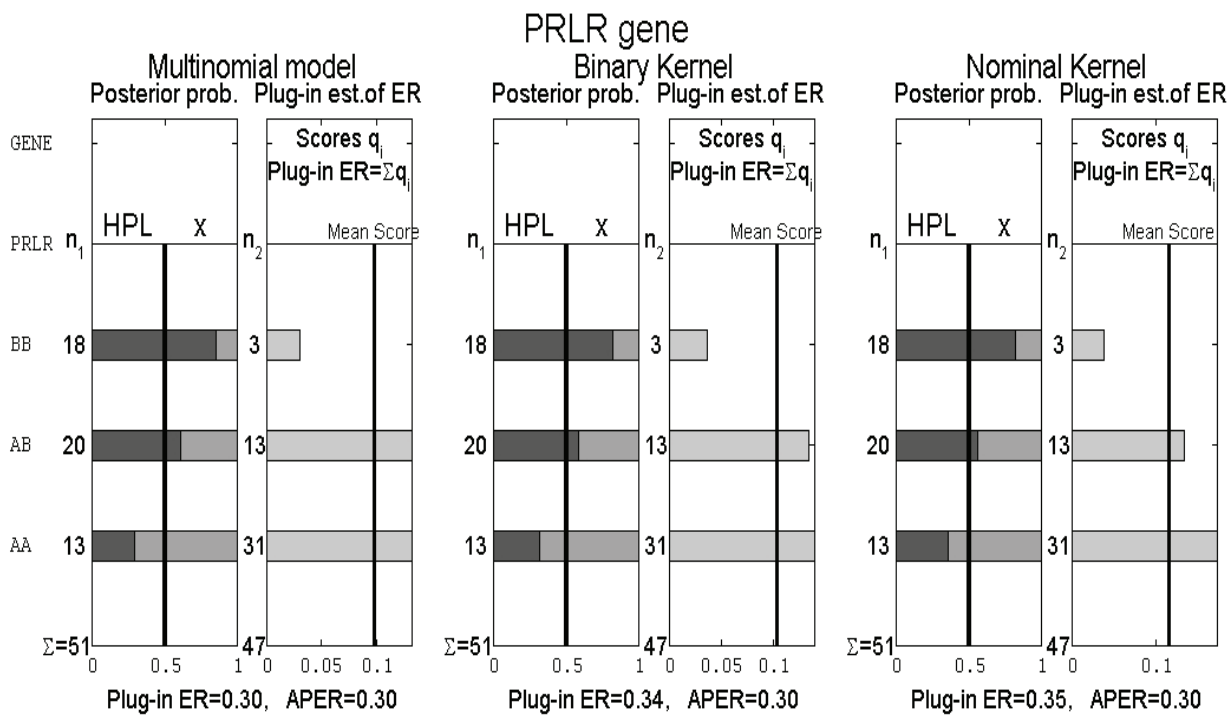

The estimated error rates are in the range: 0.30-0.35. All methods classify sow with genotype $B B$ of $P R L R$ gene into HPL (posterior probabilities $\left.p_{H P L, B B}>p_{X, B B}\right)$ and sow with genotype $A A$ into not $H P L\left(p_{H P L, A A}<p_{X, A A}\right)$.

Figure 3

Probability of the future classification of sows to HPL determined by the analysis of genotypes of PRLR gene Wahrscheinlichkeit künftiger Sauenzuordnung in die HPL auf Grund der Genotypenanalyse des PRLR Gens

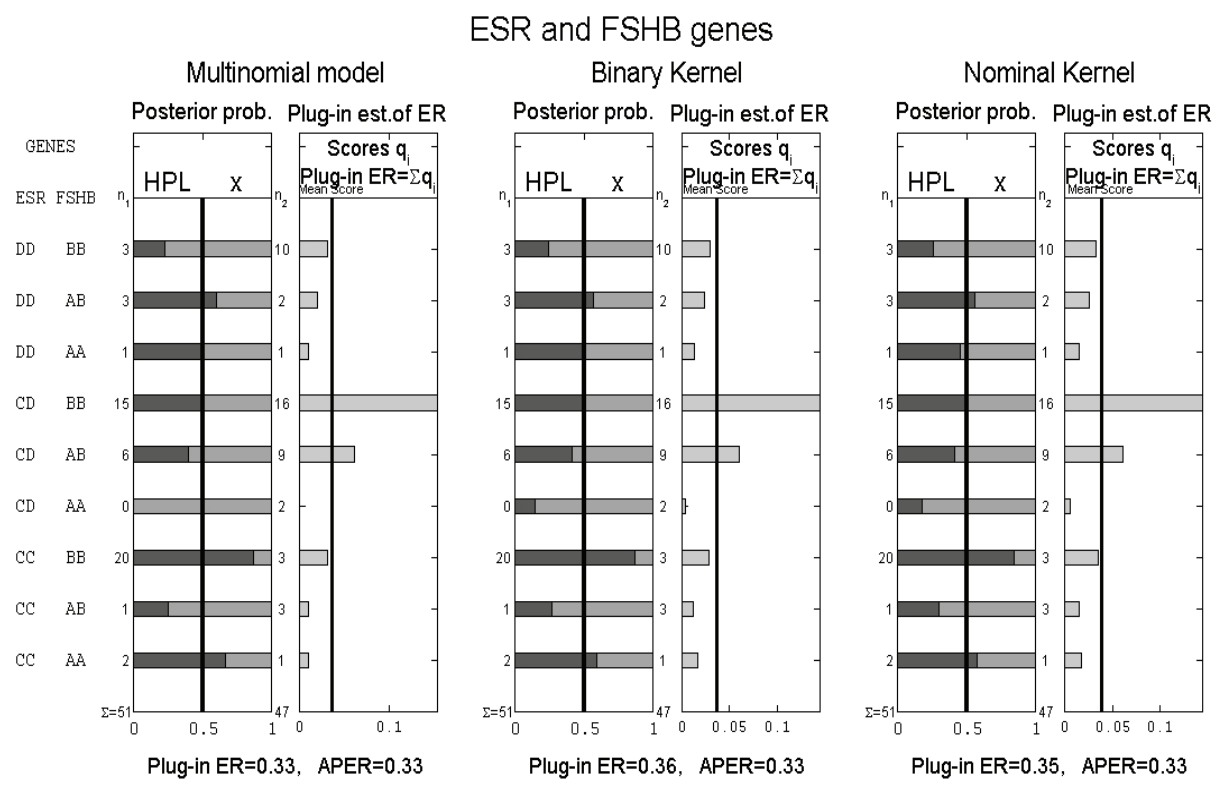

All estimated error rates are in the range: $0.33-0.36$. The sows with genotype CC of ESR gene and with genotype BB of FSHB gene are evidently classified into HPL (posterior probabilities $p_{H P L, C C \& B B}>p_{X, C C \& B B}$ ).

Figure 4

Probability of the future classification of sows to HPL determined by the analysis of genotypes of ESR and FSHB genes Wahrscheinlichkeit künftiger Sauenzuordnung in die HPL auf Grund der Genotypenanalyse der ESR-FSHB Gene 


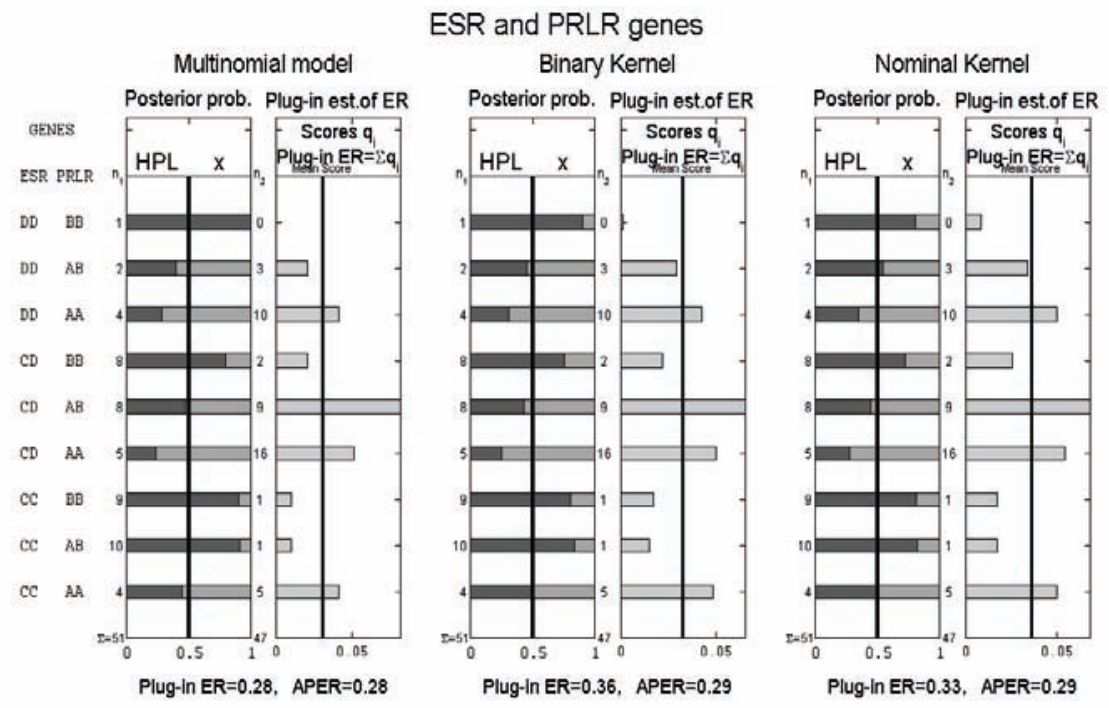

All estimated error rates are in the range: $0.28-0.36$. Each of the methods evidently classifies sow with genotype CC of ESR gene and with genotype $B B$ of PRLR gene into HPL (see posterior probabilities). The similar result is also for genotypic combination $C C$ and $A B$.

Figure 5

Probability of the future classification of sows to HPL determined by the analysis of genotypes of ESR and PRLR genes

Wahrscheinlichkeit künftiger Sauenzuordnung in die HPL auf Grund der Genotypenanalyse der ESR-PRLR Gene

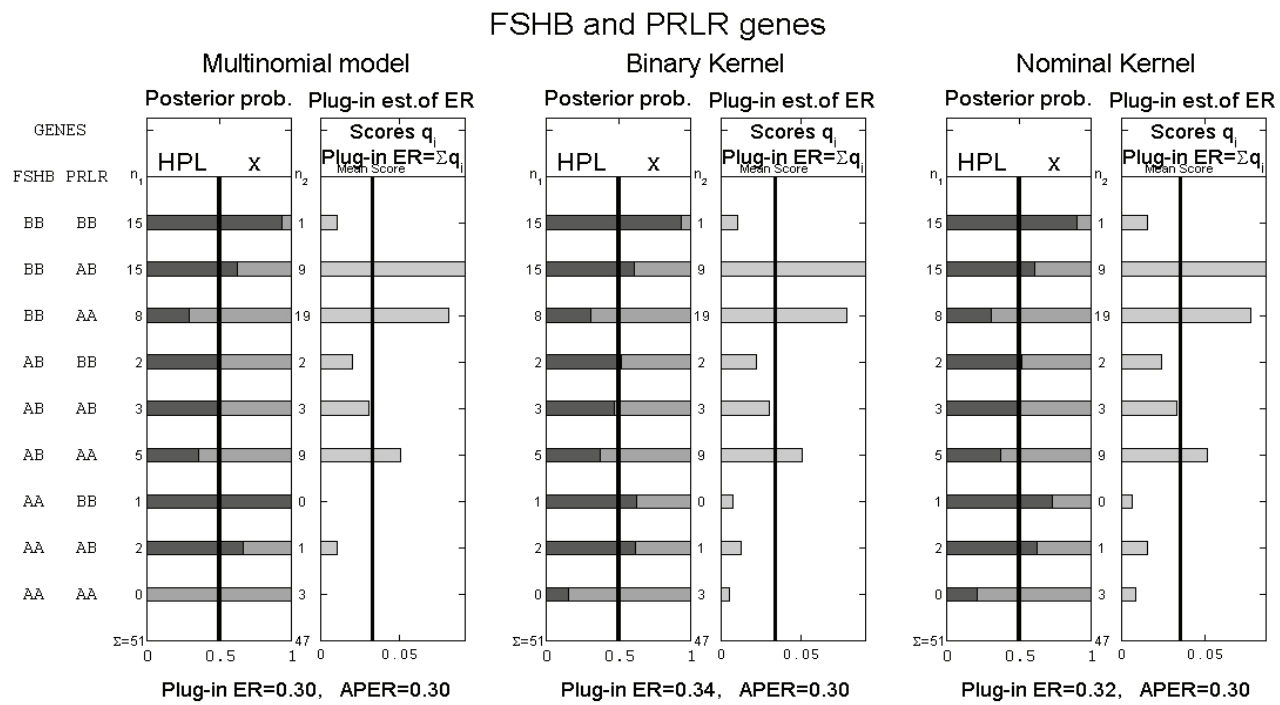

All estimated error rates are in the range: $0.30-0.34$. Parametric and nonparametric methods classify sow with genotype $B B$ of $F S H B$ gene and of $P R L R$ gene into HPL (posterior probabilities $p_{H P L B B \& B B}>p_{X, B B \& B B}$ ) and sow with genotype $B B$ (or $B A$ ) of $F S H B$ gene and $A A$ of $P R L R$ into not HPL $\left(p_{H P L, B B \& A A}<p_{X, B B \& A A}\right.$ and $\left.p_{H P L, A B \& A A}<p_{X, A B \& A A}\right)$.

Figure 6

Probability of the future classification of sows to HPL determined by the analysis of genotypes of FSHB and PRLR genes

Wahrscheinlichkeit künftiger Sauenzuordnung in die HPL auf Grund der Genotypenanalyse der FSHB-PRLR Gene 
ESR, FSHB and PRLR genes

Multinomial model

Binary Kernel

Nominal Kernel

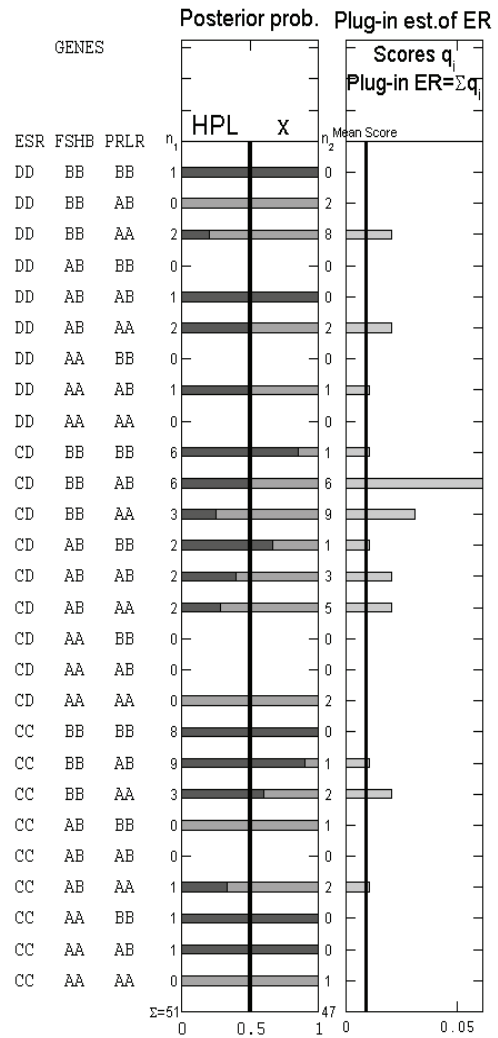

Plug-in ER $=0.24$, APER $=0.24$

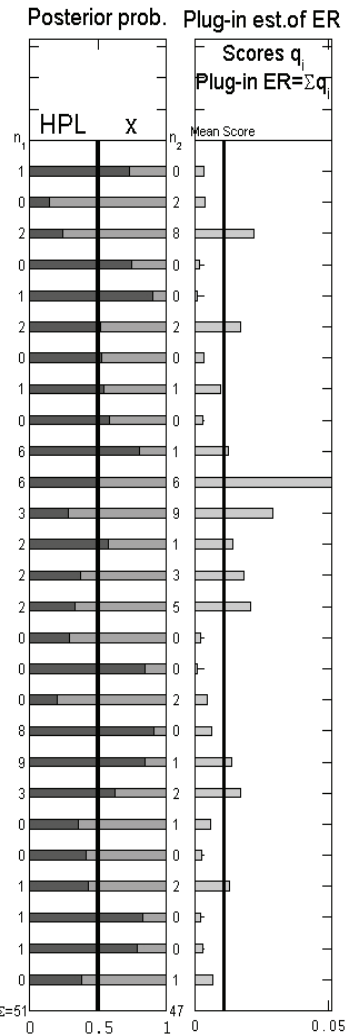

Plug-in ER=0.31, APER $=0.24$

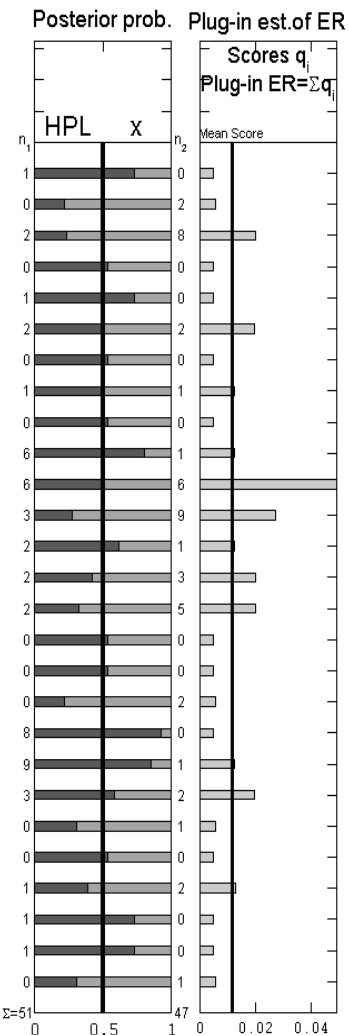

Plug-in ER=0.31, APER $=0.24$

All estimated values of the total error rate are in the range: $0.24-0.31$. The sows with genotype CC of ESR gene, genotype $B B$ of $F S H B$ gene and genotype $B B$ of PRLR gene are evidently classified into HPL (posterior probabilities $p_{H P L, C C E B B R B B}>p_{X, C C \& B B \& B B}$. In this case we can see advantage of the nonparametric methods which allow probabilities to be attached to empty cells in the training set.

Figure 7

Probability of the future classification of sows to HPL determined by the analysis of genotypes of ESR, FSHB and PRLR genes

Wahrscheinlichkeit künftiger Sauenzuordnung in die HPL aufGrund der Genotypenanalyse der ESR-FSHB-PRLR Gene

The results of the experiment indicate a possible prediction of sows on the basis of their genetic »endowment«, i.e. of a particular genotype for the classification of sows to HPL, but it is not possible to prove that the identified »beneficial" genotype will always be expressed by an increase in reproductive traits in different populations. The results of DRÖGEMÜLLER'S et al. (2001) study demonstrated that the expressions of alleles between lines or populations differed. It may be caused by diverse linkages between alleles of markers and by random mutations of different lines. The results may also be explained by a high number of minor genes influencing the litter size. The authors are convinced that a 
selection strategy should be defined for each line separately and possible pleiotropic effects should always be considered.

The originality of the paper consists in the application of discriminant analysis to predict the classification of gilts to a HPL when three selected genetic markers are determined. The studies that have been published until now demonstrate in different pig populations that the association of the genotype and alleles of genetic markers in relation to reproductive traits is not quite unambiguous. But these authors carried out »ex post « analyses, i.e. analyses of a reality only when such reality existed. The isolated evaluation of a single gene will always have a limited informative capacity and will provide applicable results only if the effect of this gene is very high and relatively independent of the genome residue and environmental conditions.

\section{Acknowledgements}

The research was supported by the project MSM 6007665806.

\section{References}

Aitchison J, Aitken CGG (1976) Multivariate binary discrimination by the kernel method. Biometrika 63, 413-20

Bidanel JP, Ducos A (1994) Genetic evaluation of Large White and French Landrace pigs for prolificacy using an animal model. J Rech Porcine Franc 26, 321-26 [in French]

Buske B, Sternstein I, Reissmann M, Reinecke P, Brockmann, G (2006) Analysis of association of GPX5, FUT1 and ESR2 genotypes with litter size in a commercial pig cross population. Arch Tierz 49, 259-68

Čermáková A, Forbelská M (2004) Parametric and nonparametric discrimination for categorical variables. Folia Fac Sci Nat Univ Masarykianae Brunensis Mathematica 15, 55-66

Chen KF, Li N, Huang LS, Zhang Q, Zhang JS, Sun SQ, Luo M, Wu CX (2001) The combined genotypes effect of ESR and FSH beta genes on litter size traits in five different pig breeds. Chinese Sci Bull 46, 140-3

Depuydt J, De Smet S, Grijspeerdt K, Herman L (1999) Association study of an Aval and Pvull polymorphism at the porcine estrogen receptor (ESR) gene with litter size. Arch Tierz 42, 172-4

Drögemüller C, Hamann H, Thieven U, Krieter J, Distl O, Harlizius B (1999) Influence of the genome region surrounding the estrogen receptor $(E S R)$ gene on litter size in a German Landrace population. Arch Tierz 42, 175-7

Drögemüller C, Hamann H, Krieter J, Presuhn U, Wallenbur GJ, Distl O (2000) Candidate gene markers connected to litter size in German pigs. In: 27th International Conference on Animal Genetics, University of Minnesota Minneapolis 26, B016

Drögemüller C, Hamann H, Distl O (2001) Candidate gene markers for litter size in different German pig lines. J Anim Sci 79, 2565-70

Dvořák J (1999) Small genetics in pigs I. MZLU v Brně [in Czech]

Hall P (1981) On nonparametric multivariate binary discrimination. Biometrika 68, 287-94

Huang LS, Chen KF, Li N, Ren J, Ding NS, Meyer JN, Besenko SP, Gao J, Luo M (2000) Genetic variations at the type I and type II markers loci in different Chinese local and Western commercial pig breeds. In: 27th International Conference on Animal Genetics, University of Minnesota Minneapolis 66, C031

Humpolicek P, Urban T, Horak P (2006) Influence of ESR1 and FSHB genes on litter size in Czech Large White sows. Arch Tierz 49, 152-7

Legault C, Gruand J, Lebost J, Garreau H, Ollivier L, Messer LA, Rothschild MF (1996) Frequency and effect on prolificacy of the ESR gene in two French Large White lines. J Rech Porcine France 28, 9-14 [in French]

Linville RC, Pomp D, Johnson RK, Rothschild MF (2001) Candidate gene analysis for loci affecting litter size and ovulation rate in swine. J Anim Sci 79, 60-7

Matoušek V, Kernerová N, Kolaříková O, Kř́žová H, Urban T, Vrtková I (2003) Effect of RYR1 and ESR genotypes on the fertility of sows of Large White breed in elite herds. Czech J Anim Sci 48, 129-33 
Omelka R, Peskovicova D, Martiniakova M, Bauer M, Bauerova M (2006) Effect of the estrogen receptor $(E S R)$ and ryanodine receptor $(R Y R 1)$ genes on reproductive traits of Slovak Large White, White Meaty and Landrace pigs. Arch Tierz 49, 357-62

Rothschild MF (1996) Genetics and reproduction in the pig. Anim Reprod Sci 42, 143-51

Southwood O, Short TH, Plastow GS, Rothschild MF (1999) A genetic marker for litter size in Landrace based pig lines. In: Proc 50th Annual Meeting of the European Association of Animal Production Zürich, GPH 1.2

Van Rens BTTM (2001) Physiological aspect of two candidate gene for litter size in pigs ESR and PRLR. [PhD Study] Wageningen

Van Rens BTTM, van der Lende T (2002) Litter size and piglet traits of gilts with different prolactin receptor genotypes. Theriogenology $57,883-93$

Van Rens BTTM, Evans GJ, van der Lende T (2003) Components of litter size in gilts with different prolactin receptor genotypes. Theriogenology 59, 915-26

Vincent AL, Evans G, Short TH, Southwood OI, Plastow GS, Tuggle CK, Rothschild MF (1998) The prolactin receptor gene is associated with increased litter size in pigs. In: Proc 6th World Congress on Genetic Applied to Livestock Production 27, 15-8

Wang XF, Wang AG, Fu JL, Lin HC (2006) Effects of ESR1, FSHB and RBP4 genes on litter size in a Large White and a Landrace herd. Arch Tierz 49, 64-70

Zhang SJ, Xiong YZ, Den CY, Xiao SM, Xu JX, Xia Y, Liu XH, Wang CF, Sun SL (2004) FSHR gene mutation and its effect on litter size in pigs. Asian Austral J Anim 17, 179-82

Received 14 May 2008, accepted 11 November 2008.

Corresponding author:

Ing. NADĚŽDA KERNEROVÁ, Ph.D.

email: kerner@zf.jcu.cz

Department of Special Animal Husbandry, Faculty of Agriculture, University of South Bohemia in České Budějovice, Studentská 13, 37005 České Budějovice, Czech Republic 